\title{
Significance of Function and Position of the Forensic Doctor in Proving Material Truth (Study on the Case of Planned Murder)
}

\author{
Tiwi Ambarwati ${ }^{1}$, Megawati Barthos ${ }^{2}$ \\ Doctoral Student of Law Program, Borobudur University, Jakarta Indonesia ${ }^{1}$, Borobudur \\ University, Jakarta Indonesia ${ }^{2}$ \\ \{tiwiambarwati63@gmail.com¹, megawati@borobudur.ac.id²\}
}

\begin{abstract}
The purpose of this study is to explain function and position of the forensic doctor in assisting in the clarity of a murder crime so that autopsy is needed in order to know the cause of death, the mechanism of death, and assisting in estimating the time of death and the manner of death. The method used in this study is normative juridical approach that is reviewing decision Number 79/Pid.B/2012/PN.BGR which in the judge's decision does not use the autopsy process. Legal material collected is through literature study approach or with secondary data. The results of the study indicate that the judge in deciding the case against the suspect is not equipped with information on the results of the autopsy and only uses visum et repertum, the results does not explain the cause of the victim death.
\end{abstract}

Keywords: Plannes murder; Forensic Medicine; Material Truth

\section{Introduction}

The main function of the criminal justice process is to find the truth as far as it can be achieved by humans and without having to sacrifice the rights of the suspect. [1] In Article 7 paragraph (1) letter (h) of the Criminal Procedure Code (KUHAP) that the investigator has the authority to bring in the experts required in connection with the examination of the case that is the forensic doctor who has special expertise or in other terms forensic medicine science, legal medicine, and medical jurisprudence). [1] The existence of forensic doctor is an absolute thing and cannot be ignored because the investigation process must be supported by science. [2]

As an independent expert witness, the doctor can assist the court by providing expert opinion based on his knowledge and experience of the facts and informing the court regarding special expertise. [3] If any victim dies, the doctor can explain the cause of death, the mechanism of death, and assist in estimating the time of death and the manner of death. [2] Visum Et Repertum on corpses is evidence of letter which is used as a basis for judges in deciding a case, in addition to the witness' and the defendant' testimonies as determined by the Criminal Procedure Code (KUHAP). [4] In this study examines the decision of judges related to the case of planned murder and the perpetrators have been legally processed with the Decision Number 79/Pid.B/2012/PN.BGR. Judges who decide their cases use visum et repertum Number P.02/024/X/201 and Number P.02/025/X/2011. The doctor who makes 
Visum et repertum states that blisters and bruises are found on the face, shoulders, compressed blisters on the neck caused by blunt force that is appropriate for the snares, but the cause of death is not found because there is no surgical autopsy. [5] The purpose of this study is to examine the role of forensic medicine in supporting evidence of a murder crime and to examine the relationship between function and position of the forensic medicine with an act of criminal murder.

\section{Research Method}

This study uses normative juridical approach that is the study that refers to legal norms and uses secondary data. The normative legal study is a study that uses secondary data sources or also called literature legal study, in which the law is conceptualized as a system of collection of positive norms in people's lives. [6]

The data used is legal material in the form of secondary data, namely primary legal material, secondary legal material, and tertiary legal material. The primary legal material is legal material which has the authoritative nature, it means that it has a certain authority. [7] The secondary legal material is a guide in this study while the tertiary legal material is support with a variety of understanding needed to clarify issues related to terminology that require explanation. The primary legal material used in the form of regulation and Decision Number 79/Pid.B/2012/ PN.BGR. Data analysis is carried out in descriptive analytic, it is done by explaining the results of the judge's decision related to the significance of function and position of the forensic doctor in order to find out the material truth.

\section{Result and Discussion}

\subsection{Visum Et Repertum}

Visum et repertum is a written report made by a doctor who has taken an oath of office, based on what has been seen and found on examination of the dead or injured allegedly due to criminal acts. [8] The term visum et repertum is contained in State Gazette (Stbl) of 1937 Number 350 regarding visa reperta. Decree of the Ministry of Justice Number M04/UM/01.06 of 1983 Article 10 states that the results of the examination of judicial medical science is called visum et repertum. The forensic doctor has a duty to examine and collect various evidence relating to the fulfillment of the elements of offense as stated by law, and compiling visum et repertum report.

Visum et repertum is information made by a doctor at the request of authorized investigator regarding the results of medical examination on the humans, living or dead or parts/suspected parts of the human body, based on scientific knowledge and under oath for the benefit of the judiciary. Visum Et Repertum is very important in proving criminal cases, one of them is the criminal murder or the death of someone who is not reasonable because of the results of examination on the body of a corpse by the forensic doctor.

\subsection{Types of Visum et Repertum}

There are several types of visum et repertum as follows [9]:

a. Visum et repertum for live patients is given if after examination of the victim requires 
further treatment for observation.

b. Visum et repertum for the deceased patient is made after corpse examination and forensic post-mortem examination at the request of the investigator.

c. Visum et repertum for the crime scene examination, made after the doctor has finished the examination at the crime scene.

d. Visum et repertum for exhumation is made after the doctor has finished the exhumation.

e. Visum et repertum for victims of moral offenses committed against rape victims.

f. Visum et repertum for evidence carried out to examine evidence relating to a crime such as blood, seminal spot, bullet casing, knife

\subsection{Autopsy}

In general, there are three types of autopsy, namely:

a. Clinical autopsy, it is carried out at the hospital with the consent of the closest relative of the corpse and the purpose is to find the abnormalities of the causes of death from the corpse, and to determine the truth.

b. Anatomical autopsy, it is carried out by medical students in studying the arrangement of tools and tissues of the human body.

c. Judiciary autopsy, it is carried out at the request of the investigator regarding a request letter of visum et repertum on the corpse. The purpose is to determine the cause and effect relationship by someone related to the victim body so that it can assist the judge in giving consideration in deciding a criminal case.

The importance of conducting judicial autopsy is to determine the certain cause of death of the victim. Because, without the judiciary autopsy is conducted, the certain cause of death cannot be determined. The result of subsequent examination is set forth in a letter called Visum et repertum of the corpse. The other interest is to assist investigators in uncovering a criminal case, for example, a murder case. Furthermore, it helps to estimate the time of death of a murder victim, the estimated time of death is very important because it is used to match the suspect's confession. However, before the doctor conducts autopsy it must be based on a request from an investigator from the Police because if there is no such request, the doctor has no obligation to do the autopsy. [5]

Finding the truth is the basis or reference in conducting a criminal investigation. [10] Judges must not convict a person unless with at least two valid evidences and gain the conviction that a criminal act actually has occurred and the defendant has committed it. [8] The valid evidence is: a. witness testimony; b. expert testimony; c. letter; d. instruction; e. defendant's testimony. The expert witness testimony is a testimony given by someone who has special expertise about what is needed to make clear a criminal case for examination purposes. [11] Therefore, the forensic doctor plays an important role in discovering material truth, it cannot be separated to enforce the law, especially in the context of proving someone's mistakes related to the body or human body parts. In the case of an investigator in the interest of the judiciary dealing with a wounded victim, poisoning or death allegedly due to an event which constitutes a criminal offense, he/she is authorized to submit requests for expert testimony to the judicial medical expert or doctor and/or other experts. [4] In addition, the doctor in conducting autopsy must get permission from the victim's family. Without a permit from the family, the doctor does not dare to do autopsy for fear of being disputed, not considering to the rights of patients and their families. 


\section{a) The Role of the Forensic Doctor in Supporting Material Truth}

This study refers to the murder case where the perpetrator has been convicted with the Decision Number 79/Pid.B/2012/PN.BGR. The decision is the enforcement of criminal law in the adjudication phase, or examination by the judge in the context of verification before the court. In the law enforcement subsystem of adjudication phase, the examination at the court level cannot be separated from the pre-adjudication phase on the case investigation and prosecution process. The absence of forensic post-mortem in making visum et repertum on the corpse is closely related to the investigation and prosecution process by the police and judiciary. [12] Investigation is the stage of the process of finding material truth as the main purpose of criminal procedure in Indonesia. Carelessness in the investigation process will be fatal in the verification process during the hearing. [13]

An important stage related to the search for material truth is that in the production of visum et repertum no forensic post-mortem is performed. On the other hand, neither the investigator nor the public prosecutor mattered. Indeed, with the completeness of the evidence of the case, witness testimony, the defendant testimony, and a letter in the form of visum et repertum that is made without forensic post-mortem, in principle has fulfilled the requirements for prosecution of the four defendants. Related to the Decision Number 79/Pid.B/2012/PN.BGR, the police agency as the spearhead in this case should be responsible for visum et repertum without forensic post-mortem, and asks the doctor to re-examine the examination in the corpse. In addition, the investigator is authorized to reject the results of the examination carried out without the forensic post-mortem. On the other hand, the public prosecutor has the authority to return the investigation file, if the forensic post-mortem is indeed needed in the results of visum et repertum. Related to the case is based on the evidence and means of proof as well as visum et repertum which is made without forensic post-mortem, the judge finally believes and decides that the perpetrator is found guilty so that he is sentenced seventeen years imprisonment to the Defendant I and the Defendant II, and fourteen years to the Defendant III and the Defendant IV.

Article 134 of the Criminal Procedure Code (KUHAP) determines: (1) In the case where it is absolutely needed for the purposes of proving post-mortem examination is no longer possible to be avoided, the investigator must notify the victim's family in advance; (2) In the case that the family is objection, the investigator is obliged to explain clearly the intent and purpose of the surgery; (3) If within two days no response from the family or the party that is notified is not found, the investigator shall immediately implement the provisions as referred to in Article 133 paragraph (3) of the Criminal Procedure Code (KUHAP), the corpse examination and/or forensic post-mortem examination depends entirely on the request of the investigator who set forth in a request letter of visum et repertum aimed at health service facilities. In the context of making visum et repertum, an important role is in the police agency as an investigator. The preliminary means of evidence is in the form of visum et repertum which is not based on forensic post-mortem, indeed, it has fulfilled the requirements for proof of murder, but in the absence of forensic post-mortem the result could not be determined the certain cause of death of the victim. Therefore, the material truth in the murder case is not yet perfect.

b) The Relationship Between Function and Position of the Forensic Medicine with a Criminal Murder

The testimony of expert witness is information given by someone who has special 
expertise about what is needed to make clear a criminal case for examination purposes. [11] While in the murder case with the Decision Number 79/Pid.B/2012/PN.BGR the judge decides without using the autopsy process. Special expertise possessed by the expert witness cannot be owned by just anyone, because it is a knowledge that is basically owned by a particular person. [1]

In a hearing examination of criminal case the judge who conducts hearing examination without any means of evidence, the judge will not be able to know and understand whether a crime has occurred and whether the defendant has actually committed a crime and is responsible for a criminal event, so the means of evidence is absolutely necessary and must be available, if the judiciary is faced with cases related to injury, the forensic doctor plays an important role in law enforcement to disclose evidence that can be either a body or part of the human body. [14] The role of the Forensic Doctor, to assist law enforcement officials in uncovering a crime in accordance with their expertise and knowledge about how the crime is committed by the defendant by examining the victim. [9]

In the legal process, in this case the criminal murder certainly requires proof to drag the perpetrator. The evidence includes witness testimony, expert testimony, instruction letter and the defendant's testimony. Whereas in the Criminal Procedure Code (KUHAP) states that a Judge may not convict a person unless at least two valid evidences he gains the conviction that a criminal act has actually taken place and that the defendant is guilty of committing it.

Medical science has a role in determining the causality relationship between an action and the consequences that will result from the action, both those that cause injury to the body, or that cause the death of person, where there are consequences that should be suspected of criminal offenses. Based on the results of this forensic expert's examination, it can be seen whether the injury of person, the unhealthiness person is caused by a crime or not. [15]

The forensic doctor can provide assistance in connection with the judicial process at the crime scene at the request of the investigator when conducting an examination of someone in a state of death. The examination by a forensic expert is very important because it is to reveal and find out the causes of his death. In this case, the doctor will make visum et repertum before the corpse is buried.

From the above points, it can be concluded that the forensic doctor is very instrumental in helping law enforcement officials to uncover a criminal offense that occurs from the level of investigation to the stage of the court of cases relating to the human body or soul, thus making clear a criminal act. The position of a doctor in handling crime victim by issuing visum et repertum should be realized and guaranteed the neutrality, because the help of the medical profession will greatly determine the truth.

The position of an expert is indispensable in handling murder victims because it determines the factual truth associated with crime. The main duty of a doctor in assisting in investigating criminal acts against health and human life is by making Visum Et repertum by collecting field facts and connecting them with one another logically to then take conclusion objectively.

Efforts to settle a criminal case involving the human body as evidence, the law cannot hear the case only with the knowledge in the field of law. Therefore the judge needs the help of someone who has knowledge in the field of the human body that is a judicial physician. In the case that it is necessary to clear up the problems arising in a court hearing, the presiding judge may request expert testimony and may also request that a new material submitted by the parties concerned. Thus the murder crime case is related to the decision Number 79/Pid.B/2012/PN.BGR the process does not use a post-mortem process. 


\section{Conclusion}

Based on the results of the study that have been described, it can be concluded that

a. Autopsy activity (forensic post-mortem) is very important and need to be carried out for the disclosure of a criminal case that results in death of victims caused by murder. Conducting post-mortem is intended to find material truth. The forensic post-mortem is a medical procedure carried out by the judicial physician at the request of the investigator. The judicial physician cannot do autopsy if the investigator does not ask for it. In addition, the doctor also cannot do autopsy if the patient or family is not pleased to do autopsy.

b. The relationship between forensic medicine and criminal murder cases are very close because the duty of forensic medicine is to find material truth so that the handling of the case is clearly explained by the cause and effect.

\section{Acknowledgment}

Thank you to those who have helped in this research study. To lecturers at the University of Borobudur and colleagues who have been encouraging and as constructive discussion partners in developing critical thinking ideas and ideas. Also to forensic doctors as discussion partners, to be able to produce in-depth analytical studies. To all parties who also help either directly or indirectly. Hopefully the results of this study can be useful for scientific development, especially in the forensic field.

\section{References}

[1] A. M. Idries, Penerapan Ilmu Kedokteran Forensik Dalam Proses Penyidikan. Jakarta: CV. Sagung Seto, 2011.

[2] W. W. A and S. S, Ilmu Kedokteran Forensik. Jakarta: Universitas Indonesia, 1997.

[3] Australian Medical Association, "Ethical Guidelines for Doctors Acting as Medical Witnesses." Australian Medical Association, Barton, p. 6, 2011.

[4] Y. A. T. Ohoiwutun, "URGENSI BEDAH MAYAT FORENSIK DALAM PEMBUKTIAN TINDAK PIDANA PEMBUNUHAN BERENCANA Kajian Putusan Nomor 79/Pid.B/2012/PN.BGR THE," J. Yudisial, vol. 9, no. 1, pp. 73-92, 2016.

[5] M. L. Azka, "ANALISIS KOORDINASI PENYIDIK KEPOLISIAN DAN DOKTER FORENSIK DALAM MENGIDENTIFIKASI TULANG KORBAN TINDAK PIDANA PEMBUNUHAN YANG DIDAHULUI DENGAN KEKERASAN," Universitas Lampung, 2019.

[6] R. H. Soemitro, Metodologi Penelitian Hukum dan Jurimetri. Jakarta: Ghalia Indonesia, 1988.

[7] P. M. Marzuki, Penelitian Hukum (Edisi Revisi). Jakarta: Prenada Media Group, 2014.

[8] Y. A. T. Ohoiwutun, Ilmu Kedokteran Forensic (Interaksi dan Dependensi Hukum Pada Ilmu Kedokteran). Yogyakarta: Pohon Cahaya, 2016.

[9] N. Hamdani, Ilmu Kedokteran Kehakiman. Jakarta: Gramedia, 1992.

[10] Y. A. T. Ohoiwutun, "Urgensi Pemeriksaan Kedokteran Forensik Pada Fase Penyelidikan dan Penyidikan Perkara Pidana," J. Cendikia Waskita, vol. 1, no. 2, pp. 
$110-118,2014$

[11] G. N. Kencana, "Kajian Kriminologi Pembunuhan Berencana Yang Dilakukan Istri Terhadap Suami di Wilayah Hukum Polres Binjai," Universitas Muhammadiyah Sumatera Utara, 2019.

[12] M. Reksodiputro, Hak Asasi Manusia Dalam Sistem Peradilan Pidana. Jakarta: Pusat Pelayanan Keadilan dan Pengabdian Hukum (Universitas Indonesia), 1999.

[13] Nugroho, "Rekonstruksi Wewenang Penyidik Dalam Perkara Tindak Pidana Korupsi (Kajian Kewenangan Polisi Dalam Penyidikan Tindak Pidana Korupsi)," J. Media Huk., vol. 16, no. 3, pp. 4-11, 2009.

[14] D. Prakoso, Penyidik, Penuntut Umum, Hakim. Jakarta: Bina Aksara, 1987.

[15] P. V. Chadha, Ilmu Forensik dan Toksikologi. Jakarta: PT. Widya Medika, 1995. 